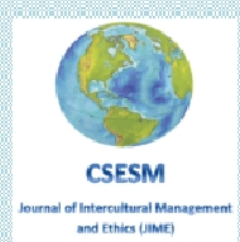

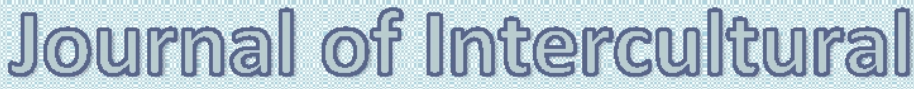

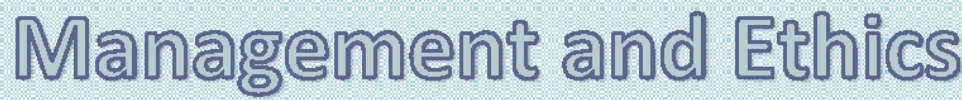

\author{
I0ME
}

ISSN 2601 - 5749, ISSN-L 2601 - 5749

Center for Socio-Economic Studies and Multiculturalism

lasi, Romania

WWW csesmioirg 


\section{TABLE OF CONTENT}

Editorial

Iulian Warter

Where Did Culture Come From? Evolutionary Foundations of Cultural Diversity

Paulo Finuras

Crash: Boeing and the Power of Culture

Thomas D. Zweifel, Vip Vyas

Political Culture, Social Polarization and Electoral Behavior. The Last Decade in Romanian

Political System

Silviu-Petru Grecu

The Principles of Transparency and Judging Others Favorably: The Talmudic View

Hershey H. Friedman, Robert B. Fireworker

Some Issues Regarding the Ethics of the Management at Romanian State-Owned

Companies .55

Baluta Aurelian Virgil, Rada Alexandru Cristian

How Does Logistics Command of the Military Navy Support Local Development and

Cultural Integration?

Rosa Caiazza

Illusion and Disillusion. Case Studies about the Constitution of a New Political Party in

Romania

Alexandru Muraru

How Could We Overcome the Feeling Of Insecurity? Explorations in the Spectrum of Polyscopic Consciousness

Anton Carpinschi

The Employees' Perceptions, Practices and Experiences Regarding the Strategic Process

Carried Out In the Public Hospitals

Ana Niculita 


\title{
ILLUSION AND DISILLUSION. CASE STUDIES ABOUT THE CONSTITUTION OF A NEW POLITICAL PARTY IN ROMANIA
}

\author{
Alexandru Muraru, $\mathrm{PhD}$ \\ Researcher in Political Science, Department of Research \\ Faculty of Philosophy and Social-Political Sciences, \\ "Alexandru Ioan Cuza" University of Iași, Romania \\ E-mail: alexandru.muraru@uaic.ro
}

\begin{abstract}
Any time social energies come together, full of hope, to constitute a political party promising to do what the current political parties have failed, we can expect people to be disillusioned; their resentments touch the fibre of democratic life. The illusion that a new party can solve the social problem and may "truly" represent the population is a future disillusion adding to the lack of trust in politics and politicians. To illustrate it, I chose a specific context in Romania and case studies featuring attempts to form political parties. At the same time, the international context plays a significant role, and it explains the most relevant trends of theoretical debates concerning the inception of a new, modern, and efficient political party. I noticed this phenomenon as it unfolded, and I saved over 150 articles and media coverages, including the extended commentaries for the period assessed. The personal observations and media appearances of the opinion leaders/trendsetters are the dominant sources of this analysis.
\end{abstract}

Keywords: illusion, political party, Snow White, disillusion, counter-democracy

\section{The risk-takers}

A precarious political culture may explain (partially) why, time and time again, hope in a salvation myth reignites (Girardet, 1997). The emergence of a new political party represents a solution to dissatisfaction related to the performances of political parties. The context may be more favourable sometimes - as many public persons thought in 2010 and 2011 - or lacking this perspective other times. However, regardless of their ability to read the signs, political risk-takers are constantly in the "fever" of "starting over". One can understand all the attempts to create new political parties as a solution to the structural or even current issues only following a reflection over time concerning this phenomenon contributing (through its perverse effects) to the discredit of political rhetoric and democratic erosion. Illusion (self-delusion) produces disillusion and disappointment, in their turn the social ferment for counter-democracy (Rosanvallon, 2010).

A new political party may be an event with echoes in public life, or it may never be more than an event like many others. Regardless of the situation, the effect is the same, which becomes apparent upon assessing the cases cumulated over a long period. I do not wish to appraise here the causes of such endeavours, which have become a phenomenon overall. They cover a wide array: real social disappointment; psychosocial need to build "a new beginning"; misunderstood political moralism; lack of historical culture regarding politics and particularly political practices may represent political calculations relying on various grounds, and the list can go on. My purpose here is to study the medium-term effects of the efforts made to consolidate a new political party. The assumption is that the major outcome of a new political party is disillusion concerning a potential higher political performance. The 
modus operandi is relatively simple. The starting point is the degree of mistrust in current politicians. The first step is an illusion or a hope for a party with "a different" type of politics. However, after acknowledging the financial, organisational, and logistical challenges of creating a political party (in fact, any organisation), we go back to square one. People lose their trust in politicians and political parties again - to which we add the negative effects of disillusion. This disillusioning illusion contributes to the erosion of trust in democracy.

The constitution of political parties is a constant of political life in post-1990 Romania, while their multitude has also led to the decreased value of such endeavours. At the same time, some of the names make any similar enterprise ridiculous (Partidul Reîntregirii Opțiunea Daco-latină (The Reunification Party - The Daco-Roman Option), partidul Renașterii Județelor Abuziv Desființate (The Party of the Rebirth of Abusively-Dissolved Counties), Partidul Național al Automobiliștilor (The National Party of Motorists), Partidul Eroilor Căzuți pentru Libertatea Eroilor Rămași în Viață Afectați de Gloanțele Barbare (The Party of the Heroes Fallen for the Freedom of Heroes Alive but Affected by the Barbaric Bullets), Mișcarea pentru Noul Mehedinți (The Movement for the New Mehedinți)) and more (Preda, 2015).

In the broader context characterised by the significant financial struggles after 2009, the general tendencies of blaming the political class have increased suddenly, not only in Romania. Several countries have recorded the emergence of political parties or movements stirring the people's attention, curiosity, and even votes. In 2009, the Five Stars Movement (Movimento 5 Stelle) emerged in Italy (an anti-establishment political formation with significant political results at the 2013 and 2018 elections). A simple search on google scholar using the name of this organisation results in over two million scientific papers and books on the topic, which indicates the attention given to this movement. In Spain, Podemos was created in 2014 (its ideological roots are in the 2011 manifestations). In Greece, Syriza officially became a political party in 2012. Authors have generally characterised the three political phenomena from the perspective of populist similarities (Segatti \& Capuzzi, 2016).

The topic of discrediting the political parties is contemporary with all electoral periods, and it is featured constantly in sociological research. Politicians, in their turn, claim the population's lack of trust in the political class (considering, firstly, the alignment to the general opinion), but they also refer to their opponents. The examples are numerous; I extracted one from the presidential campaign unfolded a decade earlier than the moment that I will develop here. Hence, in the speech addressed to the nation in 2000, the former Romanian president (who eventually won the elections that year) began his speech with "we all notice how the state authority collapsed under the ignorant eyes of an irresponsible government" (Haineș, 2002, p. 142).

In the electoral precampaign in the fall of 2009, the Romanian president Traian Băsescu stated several times that Romanians did not have to worry about the financial earthquake shaking the American markets because our country would not suffer. After winning the elections for the second term as the country's president, Traian Băsescu had to accept the reality of the financial crisis overwhelming all of Europe. One of the solutions chosen to get the economy back on its feet is one of the most severe austerity measures in the entire European Union: 25\% salary cuts for all state employees and pensioners. The announcement was made in May 2010 by the president himself. Subsequently, The Constitutional Court decided that the pension cut was unconstitutional, but the public accusation against the governing party (PDL) remained constant. The political costs were significant due to the social dissatisfactions, and a new political party (Partidul Poporului (The People's Party) - Dan Diaconescu PP-DD) entered the scene and became visible in the surveys, hoping to get enough votes for the Parliament. 


\section{Snow White as the Saviour's myth}

It is the context in which the presidential advisor Sebastian Lăzăroiu (within the Planning and Political Analysis Department of the Presidential Administration), based on various surveys, published on August 30, 2010, an ambiguous and semi-cryptical article setting out predictions for the future (local and parliamentary) elections of 2012 (Lăzăroiu, 2010). Sebastian Lăzăroiu does not use names of existing parties in the text, but characters of fairy tales and animated films, and readers try their best to interpret them. As an underlying cause of his interpretation, Sebastian Lăzăroiu starts from the statement that "the trust in the old parties and leaders has collapsed" (Lăzăroiu, 2010). This explanation makes room for the speculation that the emergence of a new party (uncompromised in the public's eyes) is imminent and that it may even end up dominating the political scene.

"A class of effects refers to the probable distribution in 2012. It seems to be the following:

The Little Red Riding Hood 26\%

The Little Match Girl 25\%

The Little Match Girl 23\%

The Goat and the Three Kids 15\%

Or it may look like this:

Snow White $35 \%$

The Little Red Riding Hood 26\%

The Little Match Girl 12\%

The Little Match Girl 12\%

The Goat and the Three Kids 8\%" (Lăzăroiu, 2010).

The Little Red Riding Hood, The Little Match Girl, Santa Claus, and The Goat and the Three Kids are PDL, PSD, PNL, and PP-DD. I will not be speculating further on this topic. It is apparent that the figures and text of Sebastian Lăzăroiu may be easily interpreted in various ways. It contributed to its tremendous success, stirring the imagination of different activists, and it led to hundreds of articles penned by influencers and trendsetting journalists, and thousands or tens of thousands of comments on the Internet.

\section{Illusion in crescendo}

Alina Mungiu-Pippidi wrote an article where she wondered who the rising stars of 2011 would be. "Clearly, the political parties organised as pirate gangs are not capable of providing the leaders we need. ( ...) With political leaders and many opinion leaders compromised by parochialism, what are our alternatives?" (Mungiu-Pippidi, 2011). The article followed another work written by the author in November 2010, where she quipped: "Political Romania seems hopeless. But civic Romania is different" (Mungiu-Pippidi, 2010). On the other hand, Vlad Mixich's intervention starts from the alliance between PNL and PC (part, in its turn, of the broader USL alliance). "Whereas there are (high) expectations, the purpose of conversations about a new political movement is bound to be sterile. The birth of such a creature requires three ingredients: money, a leader capable of communicating and understanding the people, and a network of fresh and competent leaders to collaborate for a common purpose." (Mixich, 2011) The topic was also included in the newspaper "România Liberă" through an interview with one of the best-known businessmen in Romania who owned the media trust Adevărul Holding and was a member of PNL. In the interview signed by Sabina Fati, Patriciu avoids criticising the alliance between PNL and PC, which he is not a fan of; at the same time, he states that Romanian parties need a new exchange of generations; hence, he would bet on and support a new party (Fati, 2011). 
If these articles are mere teasing tactics concerning the emergence of a new party that would dominate the political scene and restore the population's trust in the administrative and governing act, at least chronologically, Dan Tăpălagă has a straightforward approach. In an op-ed published on Hotnews.ro, he states: "The idea of founding a new party has reached the critical mass point. Practically, everyone is talking or doing something about it, in a covert or obvious manner" (Tăpălagă, 2011).

However, all these renowned characters with far-reaching audiences discuss the emergence of a particular type of party. They are looking for the background, the common denominator of the fever for a future Snow White, not any political party. Furthermore, the context is marked, as I mentioned above, by the emergence of PP-DD, by attempts made by various eccentric characters to become leaders of insignificant parties (e.g., George Becali, who led the New Generation Party and was also an MEP, or Cozmin Gușă, back then the president of the National Initiative Party). The relevant aspect in this debate and initiative is the saviour's myth: a new political party with European values and members rejecting corruption and clientelism, promoting meritocracy. Such a party would be embraced and applauded by most people who adhere to such values and would vote for it (currently lacking the alternative). "The active and honest generation needs new representatives to replace the current corrupt system of power" (Tăpălagă, 2011). These authors' belief starts from the recurrent emotional response, entailing that the political class is a failure, that it no longer represents the society, that the trust in political parties has collapsed, that there is plenty of room for a new party to grow on the political market. It would be enough to find a new leader who communicates well, get funds, and then apply a recipe. The general recipe relies on the following: "the new leadership model should have a bottom-to-top approach and reunite various communities and real skills naturally". The target-pubic is the "generation of people aged 10 to 20 in 1989, not affected profoundly by communism, in full professional development. It is perhaps their time to shine, their moment to become vocal. It may be the time of energetic idealists, not bitter resigned people. Those with legitimate CVs and careers may say it is their turn. They claim the power and refuse to be pushed to the periphery of the system for good. All they lack is a vehicle and a leader. It is no longer possible to trick the exasperated generation with false role models, mediocrities, and artificially-grown pseudoleaders" (Tăpălagă, 2011a).

Hence, it is easy to summarise the theory outlined in this period. A (new) generation of risktakers, of people disappointed by politicians, but mature enough to construct a movement, a political project, a party to correct the scene dominated by compromised characters. Risktakers must be involved in the public life, active and focusing on the public wellbeing, not follow top-to-bottom orders, but generate via a common effort a bottom-to-top organisation. Hence, its own leaders can train and act when the movement gets a shape and becomes consistent. Once launched and well on the political scene, this movement, this party (Snow White) will become dominant, overshadowing naturally the old political parties (compromised and exhausted). Facing such a hurricane forcing a reset of the political class, the old parties will have to reform or disappear. The population's disappointment, the politicians' discreditation are real, and the trust in the current leaders has vanished. But this situation, whereas disastrous, is also an occasion to rebuild the Romanian politics on correct grounds, to choose people worthy of the popular votes.

Hence, it is easy to summarise the theory outlined in this period. A (new) generation of risk-takers, people disappointed by politicians but mature enough to construct a movement, a political project, a party to correct the scene dominated by compromised characters. Risktakers must be active, involved in public life, and focus on community welfare. They should not follow top-to-bottom orders but generate a bottom-to-top organisation through a joint effort. Hence, its leaders can train and act when the movement gets a shape and becomes 
consistent. Once launched and established on the political scene, this movement or party (Snow White) will become dominant, overshadowing the old political parties (compromised and exhausted) naturally. Given such a hurricane forcing a reset of the political class, the old parties will have to reform or disappear. The population's disappointment and the politicians' discredit are real, and the trust in current leaders has vanished. But this situation, whereas disastrous, is also an occasion to rebuild Romanian politics on correct grounds, to choose people worthy of the popular votes.

At that point, in the first half of February 2011, expectations had already been outlined. The theory was already formulated, and the context seemed favourable for a new (and clean) political party. There was a market for it in the sense that sociological estimates predicted the existence of a critical mass (people unrepresented by the current parties). All that lacked was the recipe, the packaging and instructions of use, the members and leaders, doctrine and ideology, the money, and initiators. Though such aspects are structural to any political party, their absence was not a dealbreaker. Risk-takers existed, despite realists who, as I will show, warned about the relevant idealistic underlayer of the burgeoning Snow-White myth.

Cristian Ghinea (a political analyst, civic activist, and constant collaborator of the journal "Dilema veche") became a decade later member of USR and a Minister during the government coalition with PNL. He was the first to propose, in 2011, a recipe for a new party, with various organisational ideas for different aspects. "Several points are essential: the structure of the members, the selection of the representatives, the money, transparency, honesty rules" (Ghinea, 2011a). The party should comprise at least several thousand members paying a membership fee; direct internal elections for all positions should be organised. Members should know what happens to their money: hence, the financial transparency ensured by public reports on the party's website, published every six months. The new party should be "aspirational - people should feel they are paying for something worthy" (Ghinea, 2011a), which can be ensured through an Ethics committee elected b members directly, not depending on any leader. The status of the new party should exclude "electoral charity" and organise the contests for positions flawlessly, with public CVs and even voting systems through the Internet in the case of several qualified candidates. "Furthermore, this party should organise and activate on the Internet, with networks and communication forums. It should have reliable rules, a system of motivations and sanctions encouraging honesty and public service" (Ghinea, 2011a). Cristian Ghinea republished the article on the Contributors platform and stirred a debate for ideas not about what the new party would do but about how it should be, given that classic parties rely on faulty grounds, while the new construction requires a different set of rules (Ghinea, 2011b).

Reactions emerge not only in the comment sections to these articles (one comment on Cristian Ghinea's articles belonged to none other than Mihail Neamțu, who plays a significant role important a year later when he leads a party claiming to be "Snow White"). There are also public reactions: some sceptical other enthusiastic, or critical, dominating the public agenda for a while. Dragoș Paul Aligică has an ironic response to the endeavour and uses quotes about the psychology of the Romanian people, belonging to Constantin Rădulescu Motru: "It takes time for Romanians to initiate anything, but it takes a second to drop it" (Rădulescu Motru cited by Aligică, 2011). It is the main idea of Aligică's argument and a reproach; in his opinion, instead of supporting a party enforcing reforms "to the best of its knowledge", many simply abandon it.

Alin Fumurescu point out the debates on the emergence of a new party, the intensity of discussions, the rich ideas vehiculated in articles and on the forums of webpages; he provides a perspective on the divergent options presented by Cristian Ghinea and Dragoș Paul Aligică: the first is an idealist, while the second embraces pragmatic experience. 
Fumurescu writes that "pragmatism is good in theory, but the practice has killed it with mathematical accuracy across history" (Fumurescu, 2011).

Vasile Ernu made a solid and well-argued analysis, where he called the generation dubbed by Cristian Ghinea unrepresented by political parties "the zero generation, the generation that became active and started facing life in the 2000s, the Zero (00) years of this century" (Ernu, 2011). Ernu salutes the debate but criticises the "managerial" approach to a political party, as proposed by Cristian Ghinea, lacking any ideology. The zero generation must assume politics ideologically and give up on the technocratic "phantasma" and on the idea of a "managerial party that fails to represent anyone else except the paying members; a party that lacks ideology and relies solely on technical instructions is neither serious nor solid. (...) Parties should not be led by employed managers, but by politicians winning after a long and arduous process of political fights and negotiations" (Ernu, 2011).

Mihnea Măruță, another relevant journalist, intervenes and provides an organisational model. Măruță believes that the new party should be organised virtually on the Internet. "If it emerges, the Virtual Party will not follow a direction but rely on the lack of direction. Not on leaders but the need for leaders. Without money, rents to pay and palpable propaganda items. Only ideas, association, and inventiveness. Its form of organisation: the group of friends, like on Facebook. The expansion and voting methods: adding to the network and likes" (Măruță, 2011). The central idea would be to avoid the expense entailed by classic party headquarters and organise strictly via the Internet, with a network-like structure, following the model of social networks. It would eliminate rent and utility fees (allowing members to attend debates or brainstormings and apply for various positions).

The international context must have played a determining part in the virtual networkbased organisation (a virtual party). The ongoing Arab spring represented, among others, a moment of optimism concerning the democratising role of social networks. At least at that point, Facebook and Twitter seemed the best solution for people in restrictive regimes to get their information, organise, and protest successfully. Over 400 thousand scientific articles are automatically listed on Google Scholar searching "Arab Spring" and "social networks". In the second part of February 2011, the crowds of dissatisfied people who did not give up and intensified their pressure had managed to remove Ben Ali, the Tunisian leader, from power. The former Egyptian leader Hosni Mubarak had announced his resignation following massive protests maintained by information circulating on the Internet and social networks. At the same time, protests also began in Libya, Yemen, and Syria. Hence, when contextualised, the idea of organising the new party following the rules tested by Internet users no longer seems exaggerated, original, or fanciful. It seemed the best solution given the spirit of the moment.

The reactions, comments, interventions multiplied exponentially. Ciprian Ciucu was a voice of the civil society, a political commentator of the "Observator cultural" newspaper and a colleague of Cristian Ghinea at the Romanian Centre of European Policies. In his intervention, he highlighted the relevance of competence and integrity for leaders. "Stop underestimating the technocrats; we can find leaders among them, too. Better ones." (Ciucu, 2011) On the other hand, sharing the same ideological orientation as Vasile Ernu, Ciprian S,iulea analysed in detail the debates on the emergence of a new political party, but the underlying idea is that "the project proposed by Cristian Ghinea is naive and anachronic because it is part of the discourses that brought to power and supported alliances like CDR and DA, but which have expired for a while now" (Șiulea, 2011). In the series of sceptical reactions, Ștefan Vlaston exposes several minimal phases necessary to initiate and organise a new party, addressing an invitation to meet face-to-face. "To those who actually wish to make an effort in this respect, I propose a meeting next Wednesday, March 2, at a location to be disclosed subsequently" (Vlaston, 2011). 
Besides the consistent analysis (some enthusiastic, other sceptical), the comment sections of the web pages became full of comments and ardent discussions. Many of them expressed hope that a new party would rely on honesty as its core value. The debate was much more comprehensive than I can detail here. Cristian Ghinea drew a series of conclusions, where he replied to most comments and the main sceptics mentioned above. What did this topic manage to obtain? "I think I succeeded in providing an organisation model. I think that the future political parties starting from this area will be hard to justify without such rules of participation and transparency (...) with whom and with what policies? Monica Macovei came as a proposition from several people spontaneously, without being asked. I agree. Monica Macovei is the natural leader of such a party" (Ghinea, 2011c). I believe people were already oversaturated by the illusion of a new party, tailored differently from traditional parties, a new party that would represent a new generation - Snow White. Cristian Ghinea proposed two things in the last article cited above: to keep the conversation going ("we are currently brainstorming") and to "keep on persuading Monica Macovei".

\section{False hope I - one person}

At this point, we know what happened with Monica Macovei, but back then, she was still the epitome of hope (as is the case with so many politicians at the beginning of their road!). I am cautious concerning any retrospective bias in this respect; my purpose here is not to state what should have been apparent from 2011 (the political path of Mrs Macovei) but highlight a pattern of illusions that a saviour leader or a clean and new party would bring what we desire from a political class: integrity, honesty, focus on the public interests.

Monica Macovei was the Minister of Justice from 2004 to 2007 - right before Romanian joined the European Union. She became known as justiciary and a fighter against corruption even before becoming a Minister, as a fighter of APADOR-CH. She was not a member of any party, but at that point, she was known as an honest technocrat. Subsequently, she joined PDL and served as an MEP twice (at the 2009 and 2014 elections). She failed to become the PDL president in 2013 (the intensity of the debate about a new Snow-White party had already dominated 2011 and 2012).

Monica Macovei also participated in the 2014 presidential elections as an independent candidate (Cristian Ghinea himself filmed clips promoting and supporting her). Macovei obtained $4.44 \%$ of the votes cast in the presidential elections. Subsequently, in 2015, she founded the M10 Party (M times 10). A year later (after obtaining only 30,000 votes for M10 at the local elections), Monica Macovei decided to be a simple member, not the party leader. From Snow White and a potential moral leader of the new party, Monica Macovei became politically insignificant, even absent. Not even her most ardent and optimistic supports could have predicted such a decline - an effect of the illusion, today disillusion.

In August 2019, the M10 Party merged with the Moldavian Force to form the Right Alternative Party.

\section{The lessons of recent history - URR}

The Union for the Reconstruction of Romania was a political party (active in 20002005). "We started up with ten people bound by the discrepancy between what we wanted from the political class and what it delivered in ten years from the Revolution" (Ghinea \& Măruță, 2011). The main political actors or the initiative group of URR comprised people from the business world, with positions such as CEO, marketing director, manager. Their communication followed the typical patterns of commercial publicity. The electoral slogans were relevant: "500,000 young people have already left. Are we going to leave, too, or do something?", "Bancorex, SAFI, FNI, PSD, PRM ... haven't you had enough? Do something for yourself!". After four years of marketing and political efforts, URR became the third 
wheel, as everyone focused on the battle between PSD and its allies on the one hand and the DA on the other. For instance, Ovidiu Tudorici, the URR candidate for president, obtained $0.36 \%$ of the votes cast in; URR as a party obtained a similar score in 2004, below 1 (little over 37,000 votes), which was a great disappointment; it failed to be part of the Parliament.

The webpage www.urr.ro is still visible, and it features the most famous supporters of the party: Gabriel Liiceanu, Andrei Pleșu, Horia-Roman Patapievici, and Victor Rebengiuc. Due to the election results, members became disillusioned, and URR disappeared in the spring of 2005 when it merged with PNT,CD to form the Christian Democratic People's Party. The latter also became irrelevant over time.

\section{False hope II - parties and leaders}

The New Republic. The Civic Force. The Popular Movement. All three coveted the vacant pace on the political market as PDL faded and surveys predicted it would fail to become part of the Parliament. All three used the same recipe: initially, they activated as an NGO, then became a political party (Dacian Cioloș used the same strategy before founding PLUS+). The turmoil surrounding Snow White, the hope that PDL would rise from its ashes and even the illusion that a new party would overcome the weaknesses displayed by PDL and save the justice reforms threatened, in their opinion, by the imminent rise to power of PSD again. All eyes were on the 2012 elections: hopes intertwined with the illusion that Snow White would be more than a promise.

In June 2012, the New Republic emerged; by all appearances, the interviews featuring the new leader, Mihail Neamțu, showed that he took a page from the book of Snow White "written" by Sebastian Lăzăroiu. According to the official website, The New Republic described itself as "a democratic platform reuniting in a coherent and visible action all the classic-liberal, conservative and Christian-democratic sensitivities, addressing right-wing citizens disappointed by the current political structures in Romania".

The outcome of all the efforts made by those who hoped that The New Republic would become a relevant actor on the political scene was insignificant. Mihail Neamțu attempted to get The New Republic Party on the same lists in 2012 as the Right Romania Alliance (i.e., PDL, The Civic Force, PNȚCD). However, he failed because The New Republic was not a political party de jure registered at a Court. In a manner best described as bizarre, Mihail Neamțu ran personally on the lists of ARD (Right Romania Alliance, on the seats negotiated with PNTCD). He ran for a position of deputy in a circumscription of the Arad County but failed to reach the Parliament. In 2015, he decided to stop this incursion, and he announced on his Facebook account his resignation as president. "There are moments in life when the hierarchy of our priorities resets" - thus began Mihail Neamțu his resignation letter. Snow White, though never more than a mirage, was no longer among the interests of the former leader. The illusion turned into a disillusion that became full-on political party switching: in 2017, Mihail Neamțu joined PNL; in 2019, he switched to PMP.

In the same timeframe, Mihai Răzvan Ungureanu was another leader claiming to coagulate a relevant political force. He was the Romanian Prime Minister for a short time (from February 2012 to April 2012), and he was demoted through a no-confidence motion (the next Prime Minister was Victor Ponta). After leading the government, Ungureanu made efforts to found a political movement. Inițiativa Civică de Centru-Dreapta (The Centre-Right Civic Initiative) was the associative vehicle whose official purpose was to be an alternative project to the political class, capable of restoring trust and hope among Romanians. "This platform of the citizens was born as a response of people who no longer allow deception and disappointment to lead to demobilisation and anomy, with nefarious consequences on the Romanian society" (M, 2012). 
The Centre-Right Civic Initiative, along with Mihai Răzvan Ungureanu, had Monica Macovei, Ioan Stanomir, and Cristian Preda as founding members. The legislation regarding the creation of the political parties was highly restrictive back then, so they preferred another solution. In 2004, Viorel Lis (a former Bucharest mayor) created The Christian Party. In 2008, the party changed its name to The Civic Force, and Lis was no longer the president. In 2012, Mihai Răzvan Ungureanu and his colleagues of the Civic Initiative enrolled in this party and acquired the majority, and in September 2012, the former Prime Minister became the president (by vote). At the elections of that autumn, The Civic Force ran in alliance with PDL and PNTCD, obtaining four seats in the Parliament. In 2013, they decided the reprise the D.A. Alliance along with PNȚCD, while in 2014, The Civic merged through absorption with PDL (subsequently, PDL joined PNL). They forgot all about the reform, the representation of the unrepresented, a different kind of politics. All the people who had illusions about it experienced the same feeling: disillusion.

I will not discuss The People's Movement further because it is a relatively wellknown party, still active (though, in the 2020 elections, it no longer managed to get a Parliament seat). However, I am mainly interested in the beginnings, the efforts made to persuade the public that they would represent the future of Romanian politics. The birth certificates of the People's Movement were signed in April 2011 (Petrovici, 2011) when the discussions about a new strong party (Snow White) that would put Romanian politics back on its feet were dominant. "The name Snow White announced a year ago by Sebastian Lăzăroiu may have been the code name of The People's Movement. The project stood a chance only outside PDL. The key to success was spontaneous coagulation of persons, groups, organisations. Keywords: novelty and credibility" (Tăpălagă, 2011b). To everyone who noticed that the eldest daughter of the president Traian Băsescu registered the brand "The People's Movement" at OSIM, its purpose was rather clear - there was no Snow White, no new party with new principles or relying on a bottom-to-top system.

\section{Conclusion}

Snow White was a domestic metaphor that took the form of a saviour's myth. However, it is not apparent at first glance that it is also the expression of a vicious circle of illusion, delusion, and disillusion (an extremely damaging process for democracy). Furthermore, an insufficiently developed political culture can easily fall into the trap of selfdelusion because, ultimately, there is nothing wrong with hoping and expecting things to get better and someone to come and fix things for most fellow citizens, if not all. However, politics has its own ironclad laws, driven by the structure of human nature, by the inevitable inertia of human societies. Hence, once the trap of hope and saviour's illusion is set, next is disillusion and lack of trust in anything a democracy has to offer. The outcome is an unexpected but fair conclusion: distrust in politicians and parties is also a creation of those who have too much hope that they can start fresh and reset the entire political life.

\section{References}

Aligică, D.P. (2011, February 19). Să facem un partid? Să facem şi două!. http://www.contributors.ro/politica-doctrine/sa-facem-un-nou-partid-sa-facem-sidoua/

Barnea, S., \& Rahat, G. (2010). Out with the old, in with the „new”: What constitutes a new party?. Party Politics, 17, 303-320. https://doi.org/10.1177/1354068810369148

Ciucu, C. (2011, February 21). Liderii viitorului partid. http://www.contributors.ro/dezbatere/liderii-viitorului-partid/

Ernu, V. (2011, February 21). GENERAȚIA ZERO a politicii românești își face Partid. http://www.criticatac.ro/4879/generatia-zero-a-politicii-romanesti-isi-face-partid/ 
Fati, S. (2011, January 20). Dinu Patriciu: Aș susține un nou partid. Romania Liberă. http://www.romanialibera.ro/opinii/interviuri/dinu-patriciu-as-sustine-un-nou-partid213818.html

Fumurescu, A. (2011, February 20). ... la răscruce: Aligică sau Ghinea (sau despre paradoxul pragmatismului II). http://www.contributors.ro/politica-doctrine/larascruce-aligica-sau-ghinea-sau-despre-paradoxul-pragmatismului-ii/

Ghinea, C. (2011a, February 16). Noul partid - rețeta. Romania Liberă. http://www.romanialibera.ro/opinii/comentarii/noul-partid-reteta-216889pagina1.html

Ghinea, C. (2011b, February 18). Rețeta pentru noul partid. Câți v-ați băga?. http://www.contributors.ro/editorial/reteta-pentru-noul-partid-cati-v-ati-baga/

Ghinea, C. (2011c, February 22). Concluzii despre partidul nou + răspunsuri pentru Ernu, Aligică, Rogozanu, Măruță. http://www.contributors.ro/dezbatere/concluzii-desprepartidul-nou-raspunsuri-pt-ernu-aligica-rogozanu-maru\%C8\%9Ba/\#comment-15467

Ghinea, C., \& Măruță, M. (2011, February 25). Cosmin Alexandru: numai un partid de nișă poate funcționa pe internet. http://www.contributors.ro/politica-doctrine/cosminalexandru-numai-un-partid-de-nisa-poate-functiona-pe-internet/

Ghinea, C. (2014, September 11). Cristi Ghinea: Votez Monica Macovei pentru tot ce a fäcut pentru DNA, pentru ANI, pentru tot ce a făcut la PE [Video]. YouTube. https://www.youtube.com/watch? $=$ =HkwVC67THqA

Girardet, R. (1997). Mituri și mitologii politice. Iași: Institutul European.

Haineș, R. (2002). Televiziunea și reconfigurarea politicului: studii de caz: alegerile prezidențiale din Romania din anii 1996 și 2000. Iași: Polirom.

Hanley, S., \& Sikk, A. (2016). Economy, corruption or floating voters? Explaining the breakthroughs of anti-establishment reform parties in Eastern Europe. Party Politics, 22, 522-533. https://doi.org/10.1177/1354068814550438

Hug, S. (2000). Studying the Electoral Success of New Political Parties: A Methodological Note. Party Politics, 6, 187-197. https://doi.org/10.1177/1354068800006002004

Ignazi, P. (1996). The Crisis of Parties and the Rise of New Political Parties. Party Politics, 2, 549-566. https://doi.org/10.1177/1354068896002004007

Lăzăroiu, S. (2010, August 30). 2012. Scufița Roșie, Moș Crăciun, Fetița cu chibrituri? Sau Albă ca Zăpada?. http://blogary.ro/2010/08/2012-scufita-rosie-mos-craciun-fetita-cuchibrituri-sau-alba-ca-zapada/

Lăzăroiu, S. (2011, January 17). [Video]. YouTube. https://www.youtube.com/watch?v=T_EosDJBems

Lucardie, P. (2000). Prophets, Purifiers, and Prolocutors: Towards a Theory on the Emergence of New Parties. Party Politics, 6, 175-185. https://doi.org/10.1177/1354068800006002003

M., R. (2012, May 28). Mihai Răzvan Ungureanu va înființa un ONG pentru coagularea dreptei, Inițiativa Civică de Centru Dreapta, și așteaptă sugestii pe e-mail. http://www.hotnews.ro/stiri-politic-12375887-mihai-razvan-ungureanu-infiinta-ongpentru-coagularea-dreptei-initiativa-civica-centru-dreapta-asteapta-sugestii-mail.htm

Macovei, M. (2015, March 1). Lansare Partid M10 - Monica Macovei. [Video]. YouTube. https://www.youtube.com/watch?v=gOP_L6hBjn8

Măruță, $\quad$ M. (2011, $\quad$ February 21). Partidul Virtual. http://www.impactnews.ro/editoriale/Partidul-Virtual-49016

Mixich, V. (2011, January 6). O nouă mișcare politică in Romania: vis sau prostie?. http://www.contributors.ro/dezbatere/o-noua-miscare-politica-in-romania-vis-sauprostie/ 
Mungiu-Pippidi, A. (2010, November 11). Partida societăţii civile. https://www.hotnews.ro/stiri-opinii-8026444-partida-societatii-civile.htm

Mungiu-Pippidi, A. (2011, January 6). Lideri pentru 2011?. Romania Liberă. http://www1.romanialibera.ro/opinii/comentarii/lideri-pentru-2011212117.html\#top_articol

Segatti, P., \& Capuzzi, F. (2016). Five Stars Movement, Syriza and Podemos: A Mediterranean Model?. In Martinelli, A. (Ed.), Populism on the Rise: Democracies Under Challenge? (pp. 47-72). Milano, Edizioni Epoke.

Petrovici, O. (2011, April 19). Ioana Băsescu cere OSIM înregistrarea mărcii „Mișcarea Populară". Romania Liberă. http://www.romanialibera.ro/actualitate/politica/ioanabasescu-cere-osim-inregistarea-marcii-miscarea-populara-222934.html

Preda, C. (2015). 25 de ani și câteva sute de partide. București: Baroque Books \& Arts.

Rosanvallon, P. (2010). Contrademocrația. Politica în epoca neîncrederii. București: Nemira.

Sikk, A. (2012). Newness as a Winning Formula for New Political Parties, British Journal of Politics and International relations, 18, 465-486. https://doi.org/10.1177/1354068810389631

Șiulea, C. (2011, February 22). Jucării pentru oameni mari: un nou partid politic. http://www.criticatac.ro/4919/jucarii-pentru-oameni-mari-un-nou-partid-politic/

Tavits, M. (2006). Party System Change: Testing a Model of New Party Entry. Party Politics, 12, 99-119. https://doi.org/10.1017/S0007123408000069

Tăpălagă, D. (2011a, February 11). Un nou partid. http://www.hotnews.ro/stiri-8294207-noupartid.htm

Tăpălagă, D. (2011b, September 27). Mișcarea Populară sau Corabia Piraţilor?. http://www.hotnews.ro/stiri-politic-10250903-miscarea-populara-sau-corabiapiratilor.htm

TVR (2011, October 9). TVR coverage about the constitution of "Noua Republică". [Video]. YouTube. https://www.youtube.com/watch?v=9hYc80V4wr8

Vlaston, Ș. (2011, February 22). Un nou partid, demolat inainte de a se naște. http://www.contributors.ro/dezbatere/un-nou-partid-demolat-inainte-de-a-se-naste/ 